\title{
Dietary Ginger Extracts Enhanced Glucose Uptake by Muscle and Adipose of Normal and Diabetic Rats via Mimicry of Insulin Action
}

\author{
Adeniyi P.O. ${ }^{1,2, *}$, Sanusi R.A. ${ }^{1}$, Obatolu V.A. ${ }^{2}$ \\ ${ }^{1}$ University of Ibadan, Ibadan, Nigeria \\ ${ }^{2}$ Institute of Agricultural Research and Training, Ibadan, Obafemi Awolowo University, Ile-Ife, Nigeria \\ *Corresponding author: doyinadeniyi@yahoo.com
}

\begin{abstract}
The mechanism for the blood glucose lowering effect of different ginger extracts is yet to be clearly understood, that of raw ginger extracts has been sparsely explored while the mechanism for the cooked ginger extract, the form in which it is mostly consumed, has not been delved into. This study was therefore designed to determine the effect of raw and cooked ginger (Zingiber officinale Roscoe) extracts on glucose uptake by the muscle and adipose of normal, streptozocin-induced and high-fat diet-induced diabetic rats. Fresh ginger rhizomes were washed, peeled, milled and sieved without adding water to obtain the raw extract. A portion of this was boiled for 1 hour to give the cooked extract. Matured male albino rats (140) were divided into two major groups with 70 rats in each group. Group A was further divided into 7 sub-groups $(n=10) 40$ of which were rendered diabetic with intraperitoneal injection of streptozocin (60 $\mathrm{mg} / \mathrm{kg}$ body weight) to mimic Type 1 diabetes while in Group B Type 2 diabetes was induced with a 12 week consumption of High-Fat Diet (HFD). The remaining 30 rats in each group were left to remain non-diabetic/ normal. Ginger extracts were administered as a daily oral dose for 4 weeks after diabetes induction. The animals were the sacrificed and glucose uptake by the muscle and adipose tissue was determined using standard analytical procedure. Mean data were compared using Least Significant Difference at $\mathrm{p} \leq$ 0.05. It was clearly evidenced that both raw and cooked ginger extracts significantly enhanced and increased glucose uptake by the muscle and adipose tissues even in the absence of insulin, hence, mimicking insulin action. Ginger in both raw and cooked forms may therefore be beneficial in the prevention and management of diabetes mellitus. Human trial is hereby recommended.
\end{abstract}

Keywords: raw ginger extract, cooked ginger extract, glucose uptake, diabetes mellitus

Cite This Article: Adeniyi P.O., Sanusi R.A., and Obatolu V.A., "Dietary Ginger Extracts Enhanced Glucose Uptake by Muscle and Adipose of Normal and Diabetic Rats via Mimicry of Insulin Action.” American Journal of Biomedical Research, vol. 5, no. 3 (2017): 46-56. doi: 10.12691/ajbr-5-3-2.

\section{Introduction}

Different extracts of ginger have been reported to effect blood glucose lowering effect in both laboratory animals and human subject with the two major types of diabetes mellitus. Mozaffari- Khosravi et al., [1] reported the blood glucose and glycated hemoglobin lowering effect of daily oral dose of $3 g$ ginger powder in Type 2 diabetic patients while Mahluji et al., [2] reported no change in Fasting Blood Glucose (FBG) and cholesterol in Type 2 diabetic patients after daily oral dose of $2 \mathrm{~g}$ ginger powder for 2 months. The prominent hypoglycemic component of ginger, [6]-gingerol, was observed to reduce FBG in insulin resistant diabetic obese mice [3] and in streptozotocin (STZ)-induced diabetic albino rats [4].

Aqueous ginger extract was reported to be effective in lowering blood glucose in STZ-induced diabetic rats [5] and alloxan-induced diabetic rats [6]. More still, ginger powder ( $7 \%$ of diet), aqueous, methanolic ginger extracts and ginger oil also reduced FBG from $295.14 \mathrm{mg} / \mathrm{dl}$ in diabetic control to $133.81,125.19,122.17$ and $122.14 \mathrm{mg} / \mathrm{dl}$ respectively in STZ-induced diabetic rats [7]. All these ascertained the hypoglycemic effect of ginger but there are limited scientific findings on the hypoglycemic effect of raw ginger extract while there exists no report on the effect of cooked ginger extract (the form in which the spice is commonly consumed) on blood glucose.

Also fresh ginger juice (4ml/kg body weight) and dry ginger methanolic extract given at an oral dose of $0.5 \mathrm{~g} / \mathrm{kg}$ body weight reduced fasting blood glucose and increased serum insulin levels in streptozotocin-induced $(90 \mathrm{mg} / \mathrm{kg}$ body weight) diabetic rats [8], though the diabetes induced could not have been Type 1 diabetes mellitus as reported and the dose used in diabetic induction is a lethal dose. Acute effect of aqueous ginger extract ( $8 \mathrm{~g} / \mathrm{kg}$ body weight) administered intraperitoneally was similar to that of chlorpropamide in lowering blood glucose in STZ-induced diabetic rats [9] However, how the diabetic state was induced was not clearly stated. More still, methanolic ginger extract $(250 \mathrm{mg} / \mathrm{kg}$ body eight) produced a 
significant reduction in fructose-induced elevated lipid levels, body weight, hyperglycemia and hyperinsulinemia in rats while ethyl acetate extract of this spice only reduced body weight and lipid levels with no effect or change in the blood glucose and insulin levels [10]. This was because the hypoglycemic agent in ginger (gingerol) was observed to be very low in the ethyl acetate extract. However the period for which the fructose was given to induce the diabetic state was not stated. Islam and Choi, [11] reported no change in final body weight, fasting blood glucose, glycated hemoglobin and serum lipid profile in high-fat diet (22\% fat) in STZ-induced diabetic rats after 4 weeks administration of freeze-dried ginger powder given at $2 \%$ of the diet but there was significant increase in serum insulin, though this did not result into a significant lowering of blood glucose. The report of Islam and Choi [11] was in conflict with that of Nammi et al., [12] who observed a significant reduction in body weight, fasting blood glucose, serum insulin, total cholesterol in high-fat diet fed rats which were given 400mg.kg body weight ethanol ginger extract. The variation in these reports could be as a result of differences in period of extracts' administration or differences in the form of ginger used.

The blood glucose lowering effect of ginger was also affirmed by the report of Al-Qattan et al., [13]. According to them raw ginger extract markedly reduced fasting serum glucose in STZ-induced diabetic rats after 7 weeks administration. Also nephropathy parameters (such as; capsular space shrinkage, glomerular hypertrophy and diffusion and cytoplasmic fragmentation) noticed in the diabetic control group were less prominent in the treated group [13]. More still, aqueous extract of mixture of curry, garlic and ginger given at a daily oral dose of $300 \mathrm{mg}$ and $600 \mathrm{mg} / \mathrm{kg}$ body weight for 4 weeks exerted a blood glucose and lipid lowering effect on non-diabetic and alloxan-induced diabetic rats [14]. Al-Moramadhi [15] reported a hypoglycemic and hypocholesterolemic effect of aqueous ginger extract given at a daily oral dose of $100 \mathrm{mg} / \mathrm{kg}$ body weight for 6 weeks in broilers but no change was observed in body weight and food consumption. Similarly, petroleum ether, alcoholic and aqueous extracts of Zingiber officinale reduced blood glucose, serum cholesterol and triglyceride levels in both normal and alloxan-induced diabetic rats at acute and chronic administration [16]. The active hypoglycemic agent in ginger (6-gingerol) was also observed to lower fasting blood glucose, plasma triglyceride, total cholesterol, low density lipoprotein cholesterol and plasma insulin concentration in type 2 diabetic $\mathrm{db} / \mathrm{db}$ mice when given at a dose of $100 \mathrm{mg} / \mathrm{kg}$ body weight [17]. It also improved glucose tolerance and suppressed the generation of reactive oxygen species and restored the activity of catalase, superoxide dismutase and glutathione peroxidase (GPx) [17].

Al-Amin et al., [18] also affirmed the hypoglycemic and hypolipidemic effect of aqueous ginger extractin STZ-induced diabetic rats when administered at a daily oral dose of $500 \mathrm{mg} / \mathrm{kg}$ body weight for 7 weeks. The extract was also able to reverse diabetic complication by reducing the urinary protein in the diabetic rats. Ojewole [19] reported the hypoglycemic effect of ethanolic ginger extract given at oral doses of $50-800 \mathrm{mg} / \mathrm{kg}$ bodyweight. This effect was observed to be dose dependent.

Elshater et al., [20]; Akhani et al., [21] and Sharma and Shukla, [22] reported the hypoglycemic effect of raw ginger juice (unpeeled) but fresh ginger is commonly peeled when used for culinary purposes.

Since it is an established fact that ginger lowers blood glucose, it is therefore imperative that the mechanism through which spice exerts be well understood in order for its proper application in diabetes prevention and management, a concept which is yet to be clearly understood. The possible mechanisms through which could influence the control the blood are: inhibition of carbohydrate digesting enzymes, reducing the absorption of glucose into the blood stream, enhancing the secretion of insulin, increasing glucose uptake by body cells and tissues and inhibiting hepatic production of glucose.

The majority (75\%) of glucose uptake in the post prandial state is accomplished in the skeletal muscle in the skeletal muscle by the translocation of glucose transporter 4 (GLUT4) towards the membrane [23]. GLUT4 translocation in muscle cells is known to depend on two divergent signaling pathways. The first involves the binding of insulin to insulin receptor and the subsequent activation of phosphatidylinositol-3-kinase (PI3K) and Akt [24]. On the other hand 5' adenosine monophosphate-activated protein kinase (AMPK), regarded as cellular energy sensor, has been reported to promote GLUT4 translocation independently of insulin [25]. Ethyl acetate ginger extract was observed to enhance glucose uptake in cell lines in mice by expressing GLUT4 in cell surface [26]. While [6]-gingerol also exerted similar effect via this mechanism as well as via induction or enhancement of AMPK phosphorylation in L6 myotubes [3]. More still, [6]-gingerol regulated hepatic gene expression of enzymes related glucose metabolism towards reducing gluconeogenesis and glycogenolysis [3] which is similar to insulin influence as earlier explained. The enhancement of glucose uptake by reconstituted freeze-dried ginger juice was affirmed by Noipha and Ratanachaiyavong [27]. The ginger extract at $400 \mu \mathrm{g} / \mathrm{ml}$ markedly increased glucose uptake in L6 myotubes after 20 hours incubation. This enhancement of glucose transport by ginger was as a result of increased expression of both GLUT1 and GLUT4 mRNA. Several studies have established the blood glucose lowering effect of different ginger extracts, very few have identified the effect on glucose uptake as a possible mechanism of raw ginger in exerting this effect while the effect of cooked ginger extract, the form in which the spice is mostly consumed, on glucose uptake is yet to be explored. This study was therefore designed to determine the effect of raw and cooked ginger extracts on glucose uptake by the muscle and adipose tissue of normal and diabetic rats.

\section{Materials and Method}

\subsection{Preparation of Extracts}

The method of Akhani et al, [21] which was used by Elshater et al, [20] was used with slight modification. 


\subsection{Raw Extract}

Fresh ginger rhizomes (Roscoe variety) were purchased from Bodija market in Ibadan, Nigeria. This was identified and authenticated in the Herbarium Unit of the Department of Botany, University of Ibadan. The rhizomes were washed, peeled, washed and wet-milled (without the addition of water) with a plate attrition mill (Amuda Plate mill, India). This was then sieved with a cheese or muslin cloth and the extract was stored in tightly closed plastic jars at $2^{\circ} \mathrm{C}$ (at the closest part to the freezer in a refrigerator) until use.

\subsection{Cooked (boiled) Extract}

Raw extract was boiled at the medium heat of a 2-burner Thermo cool gas cooker (India) for 1 hour. This was then cooled and stored in plastic jars at $2^{\circ} \mathrm{C}$ until

\subsection{Formulation of High-fat Diet (HFD)}

The method of Martinello et al [28] was used with slight modification. The composition was as follows: $45 \%$ normal rat pellets (Lanko feeds, Nigeria), 30\% beef tallow, $20 \%$ full cream milk powder (Real Milk, Chellarams) and $5 \%$ table sugar. This was formulated weekly to prevent deterioration due to rancidity.

\subsection{Collection of Rats}

Four weeks old male albino rats (140) of weight range 50-55g were purchased from the Experimental Animal Unit of the Department of Veterinary Physiology, University of Ibadan, Nigeria. These were raised to desired weight range before experimentation commenced. Animals were fed normal rat pellets and tap water ad libitum and were treated according to the research protocol as approved by the U.I/ U.C.H. Ethics Review Committee (Ethical Approval Number-NHREC, 05/01/2008a).

\subsection{Induction of diabetes mellitus}

Experimental DM of the two major types (Type 1 and Type 2) was induced in the animals.

\subsection{Streptozocin-induced Diabetic Group (to Mimic Type 1 Diabetes Mellitus)}

Seventy rats of weight range 155-195g were placed in this group. Forty of the rats were rendered diabetic with intraperitoneal injection of streptozocin (Sigma Aldrich, Germany) at the dose of $60 \mathrm{mg} / \mathrm{kg}$ body weight [18] in freshly prepared citrate buffer (pH4.5). Fasting blood glucose (FBG) was monitored for 3 days with ACCU-CHEK Active Glucometer (Roche, Germany) until stable hyperglycemiaFBG $\geq 170 \mathrm{mg} / \mathrm{dl}$ was attained (29). The 70 rats in this group were divided into 7 groups and were designated thus:

\subsubsection{Group A}

NDC- Non-diabetic control group;

NDR- Non-diabetic rats given raw ginger juice $(4 \mathrm{ml} / \mathrm{kg}$ body weight);
NDCo- Non-diabetic rats given cooked ginger;

DC- Diabetic control group;

DR- Diabetic rats given raw ginger juice

DCo- Diabetic rats given cooked ginger juice;

DD- Diabetic rats given glibenclamide (anti-diabetic drug at $5 \mathrm{mg} / \mathrm{kg}$ body weight).

\subsection{High-fat Diet (HFD)-induced Diabetic Group (to Mimic Type 2 Diabetes Mellitus)}

Seventy rats of weight range 120-160g were used. Hyperglycemia was induced in forty of the rats by feeding them with the High-Fat Diet (HFD) for 12 weeks while the remaining30 rats were fed normal rat pellets (Lanko feeds, Nigeria). After 12 weeks HFD consumption animals with FBG $\geq 170 \mathrm{mg} / \mathrm{dl}$ were used for further experimentation. The rats in this group were divided into seven groups and designated thus:

\subsubsection{Group B}

$\mathrm{ND}_{2} \mathrm{C}$ - Non-diabetic control group;

$\mathbf{N D}_{\mathbf{2}} \mathbf{R}$ - Non-diabetic rats given raw ginger extract ( $2 \mathrm{ml} / \mathrm{kg}$ body weight);

$\mathrm{ND}_{2} \mathrm{Co}$ - Non-diabetic rats given cooked ginger extract;

$\mathbf{D}_{2} \mathbf{C}$ - Diabetic control group;

$\mathbf{D}_{\mathbf{2}} \mathbf{R}$ - Diabetic rats given raw ginger juice $(2 \mathrm{ml} / \mathrm{kg}$ body weight);

$\mathbf{D}_{2} \mathbf{C o}$-Diabetic rats given cooked ginger extract;

$\mathbf{D}_{2}$ D- Diabetic rats given Metformin $(200 \mathrm{mg} / \mathrm{kg}$ body weight).

\subsection{Extracts' Administration}

Raw and cooked ginger extracts (4ml/kg body weight) and the anti-diabetic drugs (glibenclamide for Group 1- $5 \mathrm{mg} / \mathrm{kg}$ body weight and Metformin for Group 2- $200 \mathrm{mg} / \mathrm{kg}$ body weight) were administered once daily for 4 weeks with gastric canula according to the designation of the groups above. The extracts' dosage was reduced to $2 \mathrm{ml} / / \mathrm{kg}$ body weight in the HFD-induced diabetic groups because the animals were showing signs of toxicity with bloodied eye lids after 2 days of administration of $4 \mathrm{ml} / \mathrm{kg}$ body weight dose)

\subsection{Effect of ginger extracts on glucose uptake by rat Biceps femoris muscle}

The method of Gupta et al., [30] was used. Skeletal muscle (Biceps femoris) was isolated from overnightfasted sacrificed rats. This was identified by a physiologist in the Physiology Department of the University of Ibadan, Nigeria and $0.250 \mathrm{~g}$ was placed immediately in $5 \mathrm{ml}$ of Krebs Ringer Bicarbonate buffer (KRB) containing $11.1 \mathrm{mM}$ glucose ( $\mathrm{pH}$ 7.2). This was done in triplicates for each group in three sets, that is, muscle alone, muscle with insulin $(10 \mu \mathrm{l})$ and muscle with ginger extracts $(10 \mu \mathrm{l})$ or drug as designated in each group. These were then incubated for 2.5 hours at $37^{\circ} \mathrm{C}$ in a $\mathrm{CO}_{2}$ incubator under $95 \%$ air and $5 \% \mathrm{CO}_{2}$. Aliquots of $10 \mu \mathrm{l}$ were removed at 0 , 30, 60, 90, 120 and 150 minutes and the glucose content determined using glucose oxidase method with Randox Kit reagents, U.K. 


\subsection{Determination of Aliquot Glucose}

Randox kit reagent, United Kingdom (GL366) was used for this assay. Reagent 1a was mixed with Reagent $1 \mathrm{~b}$ to form Reagent 1. A small quantity of the aliquot $(10 \mu \mathrm{L})$ was measured into a test tube and $1000 \mu \mathrm{L}$ of Reagent 1 was added after which the test tube was shaken for proper mixing. This procedure was repeated using the standard in place of the sample while for blank only $1000 \mu \mathrm{L}$ of the Reagent 1 was pipetted into a test tube. These were incubated for 25 minutes at room temperature $\left(25^{\circ} \mathrm{C}\right)$ after which the absorbance of the standard (Astandard) and that of the sample (Asample) against the blank was read within 60 minutes at $546 \mathrm{~nm}$. Glucose concentration was calculated thus:

$$
\begin{aligned}
& \text { Glucose concentration }(\mathrm{mg} / \mathrm{dL}) \\
& =\frac{\text { Asamplex Standard concentration }(\mathrm{mg} / \mathrm{dL})}{\text { Astandard }} .
\end{aligned}
$$

\subsection{Effect of Ginger Extracts on Glucose Uptake by Visceral Adipose Tissue of Normal and HFD-induced Diabetic Rats}

This was performed for this group but not for the STZ-induced diabetic groups because visceral fat was not found in the non-diabetic and STZ-induced diabetic groups. The procedures for the glucose uptake by muscle were repeated here using the adipose tissue in place of skeletal muscle.

\subsection{Statistical Analyses}

Descriptive statistics (mean, standard deviation) and inferential statistics (Analysis of Variance- Least Significant Difference) were used to analyze the data using Statistical Package for Social Science (SPSS) version 17.

\section{Result}

\subsection{Effect of Raw and Cooked Ginger Extracts on Glucose Uptake by the Muscle of Normal and STZ-induced Diabetic Rats}

The result of the effect of raw and cooked ginger extracts on glucose uptake by the muscle of normal and STZ-induced diabetic rats using muscle alone muscle with insulin and muscle with the extract was expressed in Table 1 to Table 3 and summarized in Table 4 .

\begin{tabular}{|c|c|c|c|c|c|c|}
\hline Groups & AG 0min & AG 30min & AG 60min & AG 90min & AG 120min & AG 150min \\
\hline NDC & $189.3 \pm 3.06$ & $169.0 \pm 1.00$ & $131.0 \pm 3.61$ & $121.3 \pm 4.04$ & $116.7 \pm 1.16$ & $110.0 \pm 2.65$ \\
\hline NDR & $192.0 \pm 3.00$ & $165.3 \pm 2.52$ & $116.3 \pm 5.51$ & $94.7 \pm 3.1$ & $85.0 \pm 3.00$ & $88.7 \pm 3.51$ \\
\hline DC & $200.0 \pm 3.00$ & $184.3 \pm 4.04$ & $146.7 \pm 1.53$ & $132.0 \pm 2.65$ & $118.7 \pm 1.53$ & $117.3 \pm 2.31$ \\
\hline DR & $197.3 \pm 2.52$ & $148.0 \pm 4.36$ & $116.3 \pm 3.22$ & $85.0 \pm 3.61$ & $71.3 \pm 3.79$ & $65.3 \pm 3.06$ \\
\hline $\mathrm{DD}$ & $202.0 \pm 3.61$ & $165.3 \pm 6.43$ & $133.7 \pm 4.51$ & $116.7 \pm 4.16$ & $102.0 \pm 6.56$ & $107.7 \pm 3.51$ \\
\hline
\end{tabular}

Table 1. Effect of raw and cooked ginger extracts on glucose uptake by the muscle of normal and STZ-induced diabetic rats (Muscle alone)

AG- Aliquot glucose (mg/dl)

NDC: Non-diabetic control

NDR: Non-diabetic rats give raw ginger juice

NDCo: Non-diabetic rtas given cooked ginger juice

DC: Diabetic control

DR: Diabetic rats given raw ginger juice

DCo: Diabetic rats given cooked ginger juice

DD: Diabetic rats given anti-diabetic drug.

Table 2. Effect of raw and cooked ginger extracts on glucose uptake by the muscle of normal and STZ-induced diabetic rats (Muscle + insulin)

\begin{tabular}{ccccccc}
\hline Groups & AG 0min & AG 30min & AG 60min & AG 90min & AG 120min & AG 150min \\
\hline NDC & $202.0 \pm 2.00$ & $179.0 \pm 4.00$ & $97.3 \pm 3.79$ & $67.0 \pm 1.73$ & $69.7 \pm 1.53$ \\
NDR & $198.3 \pm 4.04$ & $162.7 \pm 2.08$ & $142.0 \pm 3.00$ & $130.3 \pm 7.64$ & $104.3 \pm 4.93$ \\
NCo & $193.3 \pm 4.16$ & $147.7 \pm 1.16$ & $113.0 \pm 2.00$ & $88.0 \pm 7.21$ & $75.7 \pm 2.08$ & $91.3 \pm 6.81$ \\
DC & $196.0 \pm 6.56$ & $162.7 \pm 2.89$ & $126.3 \pm 5.51$ & $122.3 \pm 8.14$ & $104.7 \pm 7.57$ & $112.3 \pm 1.53$ \\
DR & $193.3 \pm 3.22$ & $141.3 \pm 5.51$ & $122.0 \pm 7.00$ & $107.3 \pm 5.86$ & $93.7 \pm 1.53$ \\
DCo & $187.0 \pm 4.58$ & $147.0 \pm 1.00$ & $111.0 \pm 3.00$ & $130.7 \pm 2.08$ & $126.7 \pm 2.31$ \\
DD & $190.7 \pm 1.53$ & $164.0 \pm 4.58$ & $139.7 \pm 4.93$ & $115.3 \pm 4.16$ & $118.3 \pm 2.52$ & $122.0 \pm 2.65$ \\
\hline
\end{tabular}

AG- Aliquot glucose $(\mathrm{mg} / \mathrm{dl})$

NDC: Non-diabetic control

NDR: Non-diabetic rats give raw ginger juice

NDCo: Non-diabetic rtas given cooked ginger juice

DC: Diabetic control

DR: Diabetic rats given raw ginger juice

DCo: Diabetic rats given cooked ginger juice

DD: Diabetic rats given anti-diabetic drug 
Table 3. Effect of raw and cooked ginger extracts on glucose uptake by the muscle of normal and STZ-induced diabetic rats (Muscle + extract)

\begin{tabular}{ccccccc}
\hline Groups & AG 0min & AG 30min & AG 60min & AG 90min & AG 120min & AG 150min \\
\hline NDC & $200.0 \pm 1.00$ & $170.3 \pm 2.31$ & $145.3 \pm 4.62$ & $129.3 \pm 2.89$ & $121.0 \pm 3.61$ & $117.0 \pm 3.00$ \\
NDR & $200.0 \pm 2.00$ & $161.3 \pm 4.04$ & $114.0 \pm 3.46$ & $102.3 \pm 2.52$ & $92.3 \pm 5.86$ & $84.7 \pm 0.58$ \\
NDCo & $198.0 \pm 2.65$ & $164.0 \pm 4.36$ & $113.3 \pm 2.08$ & $94.7 \pm 3.06$ & $85.0 \pm 2.65$ & $85.3 \pm 2.08$ \\
DC & $198.7 \pm 0.58$ & $174.3 \pm 3.22$ & $148.7 \pm 3.21$ & $134.0 \pm 4.36$ & $125.3 \pm 3.79$ & $120.0 \pm 3.61$ \\
DR & $198.7 \pm 1.15$ & $153.7 \pm 4.04$ & $113.0 \pm 2.65$ & $81.7 \pm 5.67$ & $72.3 \pm 4.93$ & $80.0 \pm 5.57$ \\
DCo & $198.3 \pm 2.31$ & $160.3 \pm 5.69$ & $125.7 \pm 2.52$ & $100.3 \pm 7.23$ & $73.7 \pm 1.53$ & $78.7 \pm 8.33$ \\
DD & $198.0 \pm 2.00$ & $154.0 \pm 4.36$ & $126.3 \pm 3.22$ & $109.3 \pm 5.69$ & $91.7 \pm 3.79$ & $89.0 \pm 4.00$ \\
\hline
\end{tabular}

AG- Aliquot glucose (mg/dl)

NDC: Non-diabetic control

NDR: Non-diabetic rats give raw ginger juice

NDCo: Non-diabetic rtas given cooked ginger juice

DC: Diabetic control

DR: Diabetic rats given raw ginger juice

DCo: Diabetic rats given cooked ginger juice

DD: Diabetic rats given anti-diabetic drug.

Table 4. Glucose uptake by the muscle of normal and STZ-induced diabetic rats as expressed in Table 1 to Table 3

\begin{tabular}{|c|c|c|c|}
\hline Groups & $\begin{array}{c}\mathrm{GU}(\mathrm{mg} / \mathrm{dl}) \\
\text { Muscle alone }\end{array}$ & $\begin{array}{c}\mathrm{GU}(\mathrm{mg} / \mathrm{dl}) \\
\text { Muscle + insulin }\end{array}$ & $\begin{array}{c}\text { GU }(\mathrm{mg} / \mathrm{dl}) \\
\text { Muscle + extract }\end{array}$ \\
\hline NDC & $79.3 \pm 5.69$ & $132.3 \pm 2.08$ & $83.0 \pm 2.00$ \\
\hline NDR & $103.3 \pm 3.06^{*}$ & $107.0 \pm 5.29 *$ & $115.3 \pm 1.53^{*}$ \\
\hline NDCo & $128.3 \pm 1.16^{*}$ & $125.3 \pm 7.57 *$ & $112.6 \pm 3.22 *$ \\
\hline DC & $82.6 \pm 1.53$ & $83.6 \pm 5.03$ & $78.6 \pm 3.22$ \\
\hline $\mathrm{DR}$ & $132.0 \pm 4.36 *$ & $109.0 \pm 4.58 *$ & $118.6 \pm 6.51^{*}$ \\
\hline DCo & $130.6 \pm 4.73^{*}$ & $68.6 \pm 3.79 *$ & $119.6 \pm 6.11^{*}$ \\
\hline $\mathrm{DD}$ & $94.3 \pm 5.86^{*}$ & $75.3 \pm 9.87^{*}$ & $109.0 \pm 5.29 *$ \\
\hline
\end{tabular}

GU- Glucose uptake

* - significantly different from the non-diabetic and diabetic control $(\mathrm{p} \leq 0.05)$

NDC: Non-diabetic control

NDR: Non-diabetic rats give raw ginger juice

NDCo: Non-diabetic rats given cooked ginger juice

DC: Diabetic control

DR: Diabetic rats given raw ginger juice

DCo: Diabetic rats given cooked ginger juice

DD: Diabetic rats given anti-diabetic drug

Within the 150 minutes of in vitro experiment in the absence of insulin and extract (Table 1) the percentage glucose taken up by NDC, NDR, DCo, DC, DR, DCo and DD were 41.89, 53.80, 64.29, 41.35, 66.90, 65.35 and $46.68 \%$ respectively. The muscle still took up glucose even in the absence of insulin and extract with the peak value observed in DR and the least value in DC. In the set in which insulin was added the percentage of glucose taken within the 150 minutes experimentation by NDC, NDR, NDCo, DC, DR, DCo and DD were 65.50 53.50,
64.82, 42.70, 56.39, 36.74 and 39.54\% respectively (Table 2). Insulin was able to enhance glucose uptake only in NDC while in DR, DCo and DD, the percentage of glucose taken up actually reduced. However, in the set in which extracts were added glucose uptake was enhanced by the extracts more than insulin in NDR, DR, DCo and DD (Table 3). The ability of the extracts to enhance glucose uptake by the muscle was clearly evidenced in Table 4 which expressed that the glucose uptake by the muscle in the absence of insulin was higher.

Table 5. Effect of raw and cooked ginger extracts on glucose uptake by the muscle of normal and HFD-induced diabetic rats (Muscle alone)

\begin{tabular}{ccccccc}
\hline Groups & AG 0min & AG 30min & AG 60min & AG 90min & AG 120min & $150 \mathrm{~min}$ \\
\hline $\mathrm{ND}_{2} \mathrm{C}$ & $204.3 \pm 0.58$ & $189.0 \pm 5.57$ & $179.3 \pm 3.79$ & $146.7 \pm 3.06$ & $134.7 \pm 3.51$ & $142.0 \pm 2.65$ \\
$\mathrm{ND}_{2} \mathrm{R}$ & $201.3 \pm 1.53$ & $178.0 \pm 1.00$ & $172.7 \pm 2.08$ & $145.0 \pm 3.61$ & $137.7 \pm 2.52$ \\
$\mathrm{ND}_{2} \mathrm{Co}$ & $207.7 \pm 2.52$ & $185.3 \pm 3.51$ & $169.0 \pm 3.00$ & $153.0 \pm 4.36$ & $146.3 \pm 2.31$ \\
$\mathrm{D}_{2} \mathrm{C}$ & $208.7 \pm 1.16$ & $193.7 \pm 3.22$ & $177.7 \pm 2.31$ & $168.0 \pm 4.00$ & $162.3 \pm 2.31$ \\
$\mathrm{D}_{2} \mathrm{R}$ & $204.3 \pm 1.16$ & $183.3 \pm 2.08$ & $158.0 \pm 2.65$ & $146.0 \pm 3.61$ & $146.0 \pm 4.61$ \\
$\mathrm{D}_{2} \mathrm{Co}$ & $202.0 \pm 2.46$ & $188.0 \pm 3.61$ & $163.0 \pm 2.65$ & $153.0 \pm 3.61$ & $144.7 \pm 4.51$ \\
$\mathrm{D}_{2} \mathrm{D}$ & $200.7 \pm 2.08$ & $187.3 \pm 2.08$ & $165.7 \pm 3.06$ & $147.7 \pm 2.52$ & $141.3 \pm 2.31$ & $147.3 \pm 2.08$ \\
\hline
\end{tabular}

AG- Aliquot glucose (mg/dl)

$\mathrm{ND}_{2} \mathrm{C}$ : Non-diabetic control

$\mathrm{ND}_{2} \mathrm{R}$ : Non-diabetic rats give raw ginger juice

$\mathrm{ND}_{2} \mathrm{Co}$ : Non-diabetic rats given cooked ginger juice

$\mathrm{D}_{2} \mathrm{C}$ : Diabetic control

$\mathrm{D}_{2} \mathrm{R}$ : Diabetic rats given raw ginger juice

$\mathrm{D}_{2}$ Co: Diabetic rats given cooked ginger juice

$\mathrm{D}_{2} \mathrm{D}$ : Diabetic rats given anti-diabetic drug 
Table 6. Effect of raw and cooked ginger extracts on glucose uptake by the muscle of normal and HFD-induced diabetic rats (Muscle + insulin)

\begin{tabular}{cccccc}
\hline Groups & AG 0min & AG 30min & AG 60min & AG 90min & AG 129min \\
\hline $\mathrm{ND}_{2} \mathrm{C}$ & $201.7 \pm 2.08$ & $186.7 \pm 3.22$ & $177.0 \pm 4.36$ & $168.0 \pm 5.57$ & $152.0 \pm 4.36$ \\
$\mathrm{ND}_{2} \mathrm{R}$ & $202.3 \pm 2.08$ & $195.0 \pm 3.61$ & $177.7 \pm 2.31$ & $158.3 \pm 2.89$ & $148.0 \pm 5.29$ \\
$\mathrm{ND}_{2} \mathrm{Co}$ & $199.0 \pm 1.73$ & $193.3 \pm 2.08$ & $184.7 \pm 3.79$ & $182.7 \pm 3.51$ & $162.3 \pm 2.52$ \\
$\mathrm{D}_{2} \mathrm{C}$ & $201.7 \pm 1.53$ & $194.7 \pm 0.58$ & $183.0 \pm 2.65$ & $165.7 \pm 3.79$ & $154.0 \pm 7.81$ \\
$\mathrm{D}_{2} \mathrm{R}$ & $197.7 \pm 1.16$ & $184.0 \pm 1.73$ & $182.0 \pm 2.65$ & $166.7 \pm 2.89$ & $152.0 \pm 8.19$ \\
$\mathrm{D}_{2} \mathrm{Co}$ & $202.0 \pm 1.73$ & $193.0 \pm 2.00$ & $181.7 \pm 2.89$ & $170.7 \pm 0.58$ & $181.7 \pm 1.53$ \\
$\mathrm{D}_{2} \mathrm{D}$ & $204.3 \pm 3.06$ & $184.0 \pm 1.00$ & $173.0 \pm 3.61$ & $163.7 \pm 3.22$ & $130.3 \pm 5.62$ \\
\hline
\end{tabular}

AG - Aliquot glucose (mg/dl)

$\mathrm{ND}_{2} \mathrm{C}$ : Non-diabetic control

$\mathrm{ND}_{2} \mathrm{R}$ : Non-diabetic rats give raw ginger juice

$\mathrm{ND}_{2} \mathrm{Co}$ : Non-diabetic rats given cooked ginger juice

$\mathrm{D}_{2} \mathrm{C}$ : Diabetic control

$\mathrm{D}_{2} \mathrm{R}$ : Diabetic rats given raw ginger juice

$\mathrm{D}_{2} \mathrm{Co}$ : Diabetic rats given cooked ginger juice

$\mathrm{D}_{2} \mathrm{D}$ : Diabetic rats given anti-diabetic drug.

Table 7. Effect of raw and cooked ginger extracts on glucose uptake by the muscle of normal and HFD-induced diabetic rats (Muscle + extract)

\begin{tabular}{|c|c|c|c|c|c|c|}
\hline Groups & AG 0min & AG 30min & AG 60min & AG 90min & AG 120min & AG 150min \\
\hline $\mathrm{ND}_{2} \mathrm{C}$ & $204.7 \pm 2.52$ & $191.3 \pm 1.16$ & $181.0 \pm 3.00$ & $163.3 \pm 4.73$ & $157.7 \pm 2.31$ & $152.0 \pm 2.65$ \\
\hline $\mathrm{ND}_{2} \mathrm{R}$ & $197.7 \pm 2.52$ & $185.7 \pm 2.08$ & $182.3 \pm 2.31$ & $157.0 \pm 3.00$ & $146.3 \pm 3.06$ & $133.3 \pm 1.53$ \\
\hline $\mathrm{ND}_{2} \mathrm{Co}$ & $199.0 \pm 4.58$ & $185.3 \pm 2.52$ & $174.7 \pm 2.89$ & $162.3 \pm 1.53$ & $151.3 \pm 2.08$ & $138.0 \pm 2.65$ \\
\hline $\mathrm{D}_{2} \mathrm{C}$ & $197.7 \pm 2.89$ & $191.7 \pm 2.51$ & $181.0 \pm 3.46$ & $167.0 \pm 1.73$ & $152.7 \pm 3.22$ & $144.0 \pm 2.65$ \\
\hline $\mathrm{D}_{2} \mathrm{R}$ & $196.7 \pm 1.53$ & $188.0 \pm 2.65$ & $173.3 \pm 2.08$ & $156.7 \pm 2.52$ & $147.0 \pm 2.65$ & $136.7 \pm 3.22$ \\
\hline $\mathrm{D}_{2} \mathrm{Co}$ & $202.0 \pm 1.73$ & $196.3 \pm 2.31$ & $184.7 \pm 3.06$ & $166.7 \pm 2.08$ & $144.0 \pm 4.58$ & $134.7 \pm 3.06$ \\
\hline
\end{tabular}

AG- Aliquot glucose (mg/dl)

$\mathrm{ND}_{2} \mathrm{C}$ : Non-diabetic control

$\mathrm{ND}_{2} \mathrm{R}$ : Non-diabetic rats give raw ginger juice

$\mathrm{ND}_{2} \mathrm{Co}$ : Non-diabetic rats given cooked ginger juice

$\mathrm{D}_{2} \mathrm{C}$ : Diabetic control

$\mathrm{D}_{2} \mathrm{R}$ : Diabetic rats given raw ginger juice

$\mathrm{D}_{2} \mathrm{Co}$ : Diabetic rats given cooked ginger juice

$\mathrm{D}_{2} \mathrm{D}$ : Diabetic rats given anti-diabetic drug.

Table 8. Glucose uptake by the muscle of normal and HFD-induced diabetic rats as expressed in Table 5 to Table 7

\begin{tabular}{|c|c|c|c|}
\hline Groups & $\begin{array}{l}\text { GU (mg/dl) } \\
\text { Muscle alone }\end{array}$ & $\begin{array}{c}\text { GU (mg/dl) } \\
\text { Muscle + insulin }\end{array}$ & $\begin{array}{c}\text { GU (mg/dl) } \\
\text { Muscle + extract }\end{array}$ \\
\hline $\mathrm{ND}_{2} \mathrm{C}$ & $59.3 \pm 4.16$ & $71.3 \pm 4.16$ & $52.7 \pm 4.93$ \\
\hline $\mathrm{ND}_{2} \mathrm{R}$ & $63.7 \pm 3.79 *$ & $68.7 \pm 1.53 *$ & $64.3 \pm 3.79 *$ \\
\hline $\mathrm{ND}_{2} \mathrm{Co}$ & $67.0 \pm 6.08 *$ & $53.3 \pm 5.51 *$ & $61.0 \pm 5.29 *$ \\
\hline $\mathrm{D}_{2} \mathrm{C}$ & $52.3 \pm 4.04$ & $56.3 \pm 3.79$ & $53.7 \pm 3.22$ \\
\hline $\mathrm{D}_{2} \mathrm{R}$ & $53.3 \pm 2.89$ & $67.3 \pm 6.11 *$ & $60.0 \pm 3.61 *$ \\
\hline $\mathrm{D}_{2} \mathrm{Co}$ & $60.7 \pm 1.16 *$ & $59.3 \pm 1.53 *$ & $67.3 \pm 1.53 *$ \\
\hline $\mathrm{D}_{2} \mathrm{D}$ & $57.3 \pm 3.51 *$ & $70.3 \pm 4.04 *$ & $61.3 \pm 2.52 *$ \\
\hline
\end{tabular}

GU -Glucose uptake

* -significantly different from non-diabetic and diabetic control (data in column)

$\mathrm{ND}_{2} \mathrm{C}$ : Non-diabetic control

$\mathrm{ND}_{2} \mathrm{R}$ : Non-diabetic rats give raw ginger juice

$\mathrm{ND}_{2} \mathrm{Co}$ : Non-diabetic rats given cooked ginger juice

$\mathrm{D}_{2} \mathrm{C}$ : Diabetic control

$\mathrm{D}_{2} \mathrm{R}$ : Diabetic rats given raw ginger juice

$\mathrm{D}_{2} \mathrm{Co}$ : Diabetic rats given cooked ginger juice

$\mathrm{D}_{2} \mathrm{D}$ : Diabetic rats given anti-diabetic drug.

\subsection{Effect of Raw and Cooked Ginger Extracts on Glucose Uptake by the Muscle of Normal and HFD-induced Diabetic Rats}

Table 5 to Table 7 show the result of the glucose uptake by the muscle (muscle alone, muscle with insulin and muscle with extract) of normal and HFD -induced diabetic rats and this analysis of which was summarized in Table 8.
The percentage of glucose uptake by the muscle alone (in the absence of insulin and extract) by $\mathrm{ND}_{2} \mathrm{C}, \mathrm{ND}_{2} \mathrm{R}$, $\mathrm{ND}_{2} \mathrm{Co}, \mathrm{D}_{2} \mathrm{C}, \mathrm{D}_{2} \mathrm{R}, \mathrm{D}_{2} \mathrm{Co}$ and $\mathrm{D}_{2} \mathrm{D}$ were 29.03, 31.60, $32.26,25.11,26.09,30.04$ and $28.60 \%$ respectively (Table 5). In the set in which insulin was added, percentage glucose uptake was 35.20, 33.91, 26.78, 27.96, 34.09, 29.36 and $34.41 \%$ in $\mathrm{ND}_{2} \mathrm{C}, \mathrm{ND}_{2} \mathrm{R}, \mathrm{ND}_{2} \mathrm{Co}, \mathrm{D}_{2} \mathrm{C}$, $D_{2} R, D_{2}$ Co and $D_{2} D$ respectively within the 150 minutes in vitro experimentation (Table 6). Insulin enhanced glucose uptake only in $\mathrm{ND}_{2} \mathrm{C}, \mathrm{D}_{2} \mathrm{R}$ and $\mathrm{D}_{2} \mathrm{D}$ compared to values in Table 5 (muscle alone) while this parameter 
notably reduced in $\mathrm{ND}_{2} \mathrm{Co}$ in the presence of insulin. The percentage glucose uptake in the presence of extract (Table 7) was similar to that of muscle alone except in $\mathrm{D}_{2} \mathrm{R}, \mathrm{D}_{2} \mathrm{Co}$ and $\mathrm{D}_{2} \mathrm{D}$ in which a slightly higher result was observed while compared with data obtained when insulin was added glucose uptake was enhanced only in the muscle of rats that were given cooked ginger juice both in non-diabetic and diabetic states (Table 7). However, insulin enhanced glucose uptake in $N_{2} C, N_{2} R, D_{2} R$ and $D_{2} D$ than the extracts and in muscle alone (Table 6). Table 8 is a reflection of the observations in Table 5 to Table 7 in a summary.

\subsection{Effect of Raw and Cooked Ginger Extracts on Glucose Uptake by ADIPOSE TISSUES of Normal and HFD-induced Diabetic Rats}

The effect of raw and cooked ginger extracts on glucose uptake by the adipose (adipose alone, adipose with insulin, adipose with extract) of normal and HFD-induced diabetic rats was expressed in Table 9 to Table 11 the analysis of which was computed in Table 12.

Table 9. Effect of raw and cooked ginger extracts on glucose uptake by adipose tissues of normal and HFD-induced diabetic rats (Adipose alone)

\begin{tabular}{cccccc}
\hline Groups & AG 0min & AG 30min & AG 60min & AG 90min & AG 120min \\
\hline $\mathrm{ND}_{2} \mathrm{C}$ & $205.0 \pm 2.65$ & $188.0 \pm 3.00$ & $166.3 \pm 2.31$ & $157.3 \pm 2.08$ & $152.0 \pm 2.00$ \\
$\mathrm{ND}_{2} \mathrm{R}$ & $203.0 \pm 1.00$ & $182.7 \pm 1.53$ & $171.3 \pm 1.53$ & $163.3 \pm 3.79$ & $151.0 \pm 1.73$ \\
$\mathrm{ND}_{2} \mathrm{Co}$ & $207.7 \pm 1.53$ & $184.3 \pm 2.08$ & $165.3 \pm 3.06$ & $156.7 \pm 3.22$ & $136.7 \pm 4.16$ \\
$\mathrm{D}_{2} \mathrm{C}$ & $200.3 \pm 1.53$ & $198.0 \pm 1.00$ & $197.3 \pm 1.53$ & $192.7 \pm 2.52$ & $189.3 \pm 2.08$ \\
$\mathrm{D}_{2} \mathrm{R}$ & $199.3 \pm 2.08$ & $192.3 \pm 3.06$ & $185.7 \pm 2.89$ & $164.7 \pm 2.52$ & $147.0 \pm 3.00$ \\
$\mathrm{D}_{2} \mathrm{Co}$ & $198.3 \pm 2.08$ & $199.7 \pm 1.16$ & $188.3 \pm 1.53$ & $162.7 \pm 2.08$ & $178.3 \pm 3.06$ \\
$\mathrm{D}_{2} \mathrm{D}$ & $198.0 \pm 2.65$ & $182.7 \pm 2.52$ & $181.0 \pm 2.65$ & $168.0 \pm 2.65$ & $121.3 \pm 3.51$ \\
\hline
\end{tabular}

AG -Aliquot glucose (mg/dl)

$\mathrm{ND}_{2} \mathrm{C}$ : Non-diabetic control

$\mathrm{ND}_{2} \mathrm{R}$ : Non-diabetic rats give raw ginger juice

$\mathrm{ND}_{2} \mathrm{Co}$ : Non-diabetic rats given cooked ginger juice

$\mathrm{D}_{2} \mathrm{C}$ : Diabetic control

$\mathrm{D}_{2} \mathrm{R}$ : Diabetic rats given raw ginger juice

$\mathrm{D}_{2} \mathrm{Co}$ : Diabetic rats given cooked ginger juice

$\mathrm{D}_{2} \mathrm{D}$ : Diabetic rats given anti-diabetic drug.

Table 10. Effect of raw and cooked ginger extracts on glucose uptake by adipose tissues of normal and HFD-induced diabetic rats (Adipose + insulin)

\begin{tabular}{|c|c|c|c|c|c|c|}
\hline Groups & AG 0min & AG 30min & AG 60min & AG 90min & AG 120min & AG 150min \\
\hline $\mathrm{ND}_{2} \mathrm{C}$ & $203.3 \pm 2.08$ & $193.3 \pm 2.08$ & $185.3 \pm 2.08$ & $163.0 \pm 2.00$ & $143.3 \pm 3.22$ & $137.0 \pm 2.00$ \\
\hline $\mathrm{ND}_{2} \mathrm{R}$ & $206.0 \pm 2.00$ & $195.0 \pm 2.65$ & $190.3 \pm 5.13$ & $176.7 \pm 2.08$ & $143.0 \pm 4.36$ & $120.3 \pm 0.58$ \\
\hline $\mathrm{ND}_{2} \mathrm{Co}$ & $204.0 \pm 2.00$ & $187.3 \pm 1.53$ & $186.3 \pm 3.79$ & $172.0 \pm 1.73$ & $144.3 \pm 0.58$ & $120.7 \pm 0.58$ \\
\hline $\mathrm{D}_{2} \mathrm{C}$ & $198.0 \pm 3.00$ & $194.3 \pm 2.08$ & $192.3 \pm 2.08$ & $192.7 \pm 2.52$ & $190.3 \pm 2.52$ & $185.7 \pm 3.22$ \\
\hline $\mathrm{D}_{2} \mathrm{R}$ & $199.0 \pm 1.00$ & $189.7 \pm 3.51$ & $168.0 \pm 2.65$ & $134.3 \pm 4.04$ & $126.0 \pm 3.61$ & $117.7 \pm 2.52$ \\
\hline $\mathrm{D}_{2} \mathrm{Co}$ & $206.0 \pm 1.73$ & $176.7 \pm 0.58$ & $185.0 \pm 2.65$ & $177.0 \pm 5.00$ & $168.0 \pm 2.65$ & $162.0 \pm 2.65$ \\
\hline $\mathrm{D}_{2} \mathrm{D}$ & $198.3 \pm 2.08$ & $187.0 \pm 2.65$ & $157.3 \pm 2.08$ & $132.7 \pm 2.52$ & $125.0 \pm 4.36$ & $115.7 \pm 3.22$ \\
\hline
\end{tabular}

AG - Aliquot glucose (mg/dl)

$\mathrm{ND}_{2} \mathrm{C}$ : Non-diabetic control

$\mathrm{ND}_{2} \mathrm{R}$ : Non-diabetic rats give raw ginger juice

$\mathrm{ND}_{2} \mathrm{Co}$ : Non-diabetic rats given cooked ginger juice

$\mathrm{D}_{2} \mathrm{C}$ : Diabetic control

$\mathrm{D}_{2} \mathrm{R}$ : Diabetic rats given raw ginger juice

$\mathrm{D}_{2} \mathrm{Co}$ : Diabetic rats given cooked ginger juice

$\mathrm{D}_{2} \mathrm{D}$ : Diabetic rats given anti-diabetic drug

Table 11. Effect of raw and cooked ginger extracts on glucose uptake by adipose tissues of normal and HFD-induced diabetic rats (Adipose + extract)

\begin{tabular}{|c|c|c|c|c|c|c|}
\hline Groups & AG 0min & AG 30min & AG 60min & AG 90min & AG 120min & AG 150min \\
\hline $\mathrm{ND}_{2} \mathrm{C}$ & $204.7 \pm 2.52$ & $191.0 \pm 2.65$ & $164.7 \pm 2.52$ & $153.3 \pm 3.51$ & $136.7 \pm 2.31$ & $139.7 \pm 4.16$ \\
\hline $\mathrm{ND}_{2} \mathrm{R}$ & $201.7 \pm 2.52$ & $190.7 \pm 2.52$ & $171.3 \pm 1.53$ & $157.0 \pm 3.61$ & $149.3 \pm 2.52$ & $120.3 \pm 2.08$ \\
\hline $\mathrm{ND}_{2} \mathrm{Co}$ & $198.3 \pm 2.08$ & $187.7 \pm 2.52$ & $168.3 \pm 1.53$ & $162.7 \pm 2.52$ & $138.3 \pm 3.79$ & $126.0 \pm 4.58$ \\
\hline $\mathrm{D}_{2} \mathrm{C}$ & $204.7 \pm 0.58$ & $193.0 \pm 1.00$ & $191.0 \pm 1.73$ & $188.0 \pm 2.65$ & $183.0 \pm 4.58$ & $181.7 \pm 6.11$ \\
\hline $\mathrm{D}_{2} \mathrm{R}$ & $198.3 \pm 1.53$ & $192.0 \pm 2.00$ & $187.7 \pm 3.06$ & $168.7 \pm 3.51$ & $148.7 \pm 4.16$ & $119.0 \pm 5.29$ \\
\hline $\mathrm{D}_{2} \mathrm{Co}$ & $202.0 \pm 1.00$ & $186.3 \pm 1.15$ & $172.0 \pm 2.00$ & $157.0 \pm 1.73$ & $145.7 \pm 3.21$ & $117.3 \pm 2.08$ \\
\hline $\mathrm{D}_{2} \mathrm{D}$ & $205.0 \pm 1.73$ & $189.7 \pm 0.58$ & $186.7 \pm 3.22$ & $154.7 \pm 2.52$ & $132.0 \pm 2.00$ & $118.0 \pm 2.00$ \\
\hline
\end{tabular}

AG - Aliquot glucose (mg/dl)

$\mathrm{ND}_{2} \mathrm{C}$ : Non-diabetic control

$\mathrm{ND}_{2} \mathrm{R}$ : Non-diabetic rats give raw ginger juice

$\mathrm{ND}_{2} \mathrm{Co}$ : Non-diabetic rats given cooked ginger juice

$\mathrm{D}_{2} \mathrm{C}$ : Diabetic control

$\mathrm{D}_{2} \mathrm{R}$ : Diabetic rats given raw ginger juice

$\mathrm{D}_{2} \mathrm{Co}$ : Diabetic rats given cooked ginger juice

$\mathrm{D}_{2} \mathrm{D}$ : Diabetic rats given anti-diabetic drug. 
Table 12. Glucose uptake by the adipose tissues of normal and HFD-induced diabetic rats as expressed in Table 9 to Table 11

\begin{tabular}{|c|c|c|c|}
\hline Groups & $\begin{array}{c}\mathrm{GU}(\mathrm{mg} / \mathrm{dl}) \\
\text { Adipose alone }\end{array}$ & $\begin{array}{c}\mathrm{GU}(\mathrm{mg} / \mathrm{dl}) \\
\text { Adipose + insulin }\end{array}$ & $\begin{array}{c}\mathrm{GU}(\mathrm{mg} / \mathrm{dl}) \\
\text { Adipose + extract }\end{array}$ \\
\hline $\mathrm{ND}_{2} \mathrm{C}$ & $63.0 \pm 1.00$ & $66.3 \pm 3.22$ & $65.0 \pm 4.58$ \\
\hline $\mathrm{ND}_{2} \mathrm{R}$ & $76.3 \pm 5.69 *$ & $85.7 \pm 2.08^{*}$ & $81.3 \pm 4.16^{*}$ \\
\hline $\mathrm{ND}_{2} \mathrm{Co}$ & $87.0 \pm 4.00 *$ & $83.3 \pm 2.52 *$ & $72.3 \pm 6.43^{*}$ \\
\hline $\mathrm{D}_{2} \mathrm{C}$ & $15.3 \pm 2.52$ & $12.3 \pm 4.04$ & $23.0 \pm 5.57$ \\
\hline $\mathrm{D}_{2} \mathrm{R}$ & $78.0 \pm 1.73^{*}$ & $81.3 \pm 1.53^{*}$ & $79.3 \pm 5.51^{*}$ \\
\hline $\mathrm{D}_{2} \mathrm{Co}$ & $22.0 \pm 1.73 *$ & $44.0 \pm 3.61^{*}$ & $84.7 \pm 1.53 *$ \\
\hline $\mathrm{D}_{2} \mathrm{D}$ & $80.0 \pm 4.36 *$ & $82.7 \pm 4.73^{*}$ & $87.0 \pm 1.00 *$ \\
\hline
\end{tabular}

GU - Glucose uptake

* --significantly different from the non-diabetic and diabetic control (data in column)

$\mathrm{ND}_{2} \mathrm{C}$ : Non-diabetic control

$\mathrm{ND}_{2} \mathrm{R}$ : Non-diabetic rats give raw ginger juice

$\mathrm{ND}_{2} \mathrm{Co}$ : Non-diabetic rats given cooked ginger juice

$\mathrm{D}_{2} \mathrm{C}$ : Diabetic control

$\mathrm{D}_{2} \mathrm{R}$ : Diabetic rats given raw ginger juice

$\mathrm{D}_{2} \mathrm{Co}$ : Diabetic rats given cooked ginger juice

$\mathrm{D}_{2} \mathrm{D}$ : Diabetic rats given anti-diabetic drug.

The adipose of the diabetic control group showed the least percentage of glucose in adipose alone (Table 9), adipose and insulin (Table 10) and adipose and extract (Table 11) while the glucose uptake by adipose alone (Table 9) as well as muscle + extract (Table 11) was comparable to that of the sets in which insulin was added and this was even higher in D2Co, adipose+ extract (Table 11), hence, the extracts enhanced glucose uptake in the absence of insulin. All these are clearly expressed in Table 12 in summary.

\section{Discussion}

\subsection{Effect of Raw and Cooked Ginger Extracts on Glucose Uptake by the Muscle of Normal and STZ-induced Diabetic Rats.}

The 4 weeks extracts administration has improved the morphology of the muscle to take up glucose even in the absence of insulin and extracts (Table 4- Muscle alone) as this was reflected in the significant increase in glucose uptake by the extracts' treated groups both in muscle of normal and diabetic groups. The significant reduction in glucose uptake by the control groups also affirms the fact that ginger extracts and drug administration for 4 weeks enhanced glucose uptake by the muscle and altered the morphology of the muscle to exert this effect since the glucose uptake significantly increased in the absence of insulin and extracts (Table 4-muscle alone).

Insulin enhanced glucose uptake by the muscle of only the non diabetic control (Table 4). The significant reduction in glucose uptake by the muscles of the diabetictreated groups in the presence of insulin could be due to undesirable interference between the action of insulin and the altered morphology of the muscles of the treated animals. It can therefore be inferred from this that ginger consumption together with the use of insulin may not produce a desirable effect on glucose uptake in STZinduced diabetic rats or Type 1 diabetic patients.

Raw and cooked ginger extracts increased glucose uptake by $38.95 \%$ and $35.75 \%$ respectively by the muscle of normal rats while in the muscle of diabetic rats the increase observed was $50.85 \%$ and $52.12 \%$ respectively and the drug treated animals muscle this was $38.55 \%$ (Table 4- muscle + extract) .This shows that ginger extracts were even more effective in enhancing glucose uptake than the drug by the muscle of the treated diabetic animals. This insulin-like activity of ginger affirms the scientific report that ginger exerts insulin-like activity in vitro [31]. The ability of [6]-gingerol to regulate the gene expression of enzymes related to glucose metabolism towards decreasing gluconeogenesis and glycogenolysis as reported by Son et al.., 2014 which is a similar function of insulin as earlier explained may further ascertain the mimicry of insulin function by ginger. The enhancement of glucose uptake by myotubes of muscles by ethyl acetate ginger extract and gingerol was also observed by Rani et al., [26] and Son et al., [3] in vitro as well as in vivo in obese diabetic mice (3). This marked increase in glucose uptake may be the induction of 5'adenosine monophosphate-activated protein kinase (AMPK) phosphorylation in L6 myotubes and the promotion of glucose transporter 4 (GLUT 4) translocation to cell membrane by [6]-gingerol and ethyl acetate ginger extract $[3,26]$.

\subsection{Effect of Raw and Cooked Ginger Extracts on Glucose Uptake by the Muscle of Normal and HFD-induced Diabetic Rats}

Glucose uptake by the muscle in these groups is lower compared to that of normal and STZ-induced diabetic rats in Table 4 even among the non-diabetic groups. This may be as a result of difference in the age of the animals in the two groups (the STZ-induced diabetic group were 4 months old while the rats in the HFD-induced group were 7 months old) coupled with the HFD diet fed to the HFDinduced diabetic groups. Four weeks administration of raw and cooked ginger extracts increased glucose uptake by the muscle of non-diabetic rats significantly in the absence of insulin and extracts while only the cooked extract and Metformin exerted this effect (Table 8, muscle alone) in the diabetic groups. The residual effect of the extracts and drug treatment could also be seen here.

Insulin enhanced glucose uptake in the muscle of nondiabetic control than that of the non-diabetic rats given 
raw and cooked ginger extracts. Insulin also significantly increased glucose uptake by the muscles of HFD-induced diabetic rats that were treated with raw, cooked ginger extracts and Metformin by 19.52\%, 5.30\% and 24.83\% respectively compared to the diabetic control.

Introduction of the ginger extracts to the medium in the absence of insulin (Table 8- muscle + extract) increased glucose uptake significantly in the muscle of non-diabetic treated groups though the increase was comparable to that in muscle alone in these two groups.

In the diabetic groups (Table 8-muscle alone) glucose uptake increased by $15.92 \%$ and $9.56 \%$ by the muscles of the animals that were treated with cooked extract and Metformin respectively while raw extract did not increase this parameter significantly. Insulin increased glucose uptake significantly by the muscles of diabetic treated rats (Table 8-muscle+insulin) while the extracts and drug increased this parameter significantly (Table 8muscle+extract) in all the groups compared to the diabetic control. The enhancement of glucose uptake by ginger extracts may be as a result of the ability of [6]-gingerol to increase AMPK $\alpha$-subunits in L6 skeletal muscle cells which enhanced glucose uptake and prevented high-fat high-calorie diet-induced insulin resistance in rats [32] as well as increasing surface distribution of GLUT 4 proteins on the L6 myotubes plasma membrane in rat skeletal muscle cells [33].

\subsection{Effect of Raw and Cooked Ginger Extracts on Glucose Uptake by Adipose Tissue of Normal and HFD-induced Diabetic Rats}

In the non-diabetic groups, glucose uptake by the adipose tissue significantly increased even in the absence of insulin and extracts showing the residual effect of the extracts on the adipose tissues in enhancing this parameter while in the diabetic rats the increase of glucose uptake by the adipose tissue was $408.81 \%, 43.51 \%$ and $421.85 \%$ in diabetic rats given raw, cooked ginger extracts and metformin respectively (Table 12-Adipose alone). This denotes a probable modification of the adipose morphology during the 4 weeks' extracts and drug administration in favor of glucose uptake.

Introduction of insulin into the medium showed similar effect but glucose uptake was enhanced least by the adipose of diabetic rats given cooked extract (Table 12adipose + insulin). This shows that the 4 weeks cooked ginger extract administration did not alter the morphology of the adipose enough to enhance glucose uptake effectively as the raw extract and Metformin. This may be due to undesirable nutrient-drug interaction.

However both extracts effect a significant increase in glucose uptake in non-diabetic and diabetic adipose tissues (Table 12-adipose + extracts). In the non-diabetic adipose, the increase was 25.14 and $11.28 \%$ in nondiabetic rats given raw and cooked ginger extracts respectively while in the diabetic adipose this was $277.76 \%$, 303.19\% and $314.29 \%$ in diabetic rats given raw, cooked ginger extracts and metformin respectively. The marked enhancement of glucose uptake by cooked extract here shows that the chronic administration of the extract may not be effective in enhancing this parameter in adipose tissue while the acute administration could be effective. However, the enhancement of differentiation of 3L3-L1 adipocytes by [6]-gingerol [34] coupled with increased peroxisome proliferator-activated receptor gamma (PPAR $)$ gene expression and facilitated GLUT4 protein translocation [35] may be responsible for the enhancement of glucose uptake by adipocytes [36].

The enhancement of glucose uptake by the muscle and adipose of the treated rats in this study was reflected in the blood glucose of the animals as reported in the earlier publication of the parts of this study as expressed in Table 13 and Table 14.

Table 13. Effect of ginger extracts on FBG in normal and STZ-induced diabetic rats

\begin{tabular}{cccc}
\hline Groups & B FBG $(\mathrm{mg} / \mathrm{dl})$ & S FBG $(\mathrm{mg} / \mathrm{dl})$ & 2 FBG $(\mathrm{mg} / \mathrm{dl})$ \\
\hline NDC & $110.30 \pm 5.59$ & $110.10 \pm 4.93$ & $112.4 \pm 3.98$ \\
NDR & $110.90 \pm 6.74$ & $111.4 \pm 2.63$ & $83.00 \pm 1.58$ \\
NDCo & $109.40 \pm 5.64$ & $111.50 \pm 3.47$ & $83.60 \pm 2.99$ \\
DC & $111.50 \pm 4.83$ & $372.40 \pm 11.81$ & $399.00 \pm 7.84$ \\
DR & $111.00 \pm 4.37$ & $369.70 \pm 13.17$ & $179.20 \pm 2.56$ \\
DCo & $109.20 \pm 5.80$ & $369.7 \pm 13.17$ & $176.80 \pm 4.83$ \\
DD & $109.80 \pm 6.84$ & $375.30 \pm 11.84$ & $164.96 \pm 9.58 \pm 2.41$ \\
\hline
\end{tabular}

B FGB- FBG before the induction of diabetes. S FBG- FBG after the induction of diabetes before extracts administration. 2 FBG- FBG at the end of 2 weeks ginger extracts administration 4 FBG- FBG at the end of 4 weeks ginger extracts administration.

Source: Adeniyi and Sanusi [37].

Table 14. Effect of raw and cooked ginger extracts on blood glucose in normal and HFD-induced diabetic rats

\begin{tabular}{cccc}
\hline Groups & A FBG $(\mathrm{mg} / \mathrm{dl})$ & B FBG $(\mathrm{mg} / \mathrm{dl})$ & $2 \mathrm{FBG}(\mathrm{mg} / \mathrm{dl})$ \\
\hline $\mathrm{ND}_{2} \mathrm{C}$ & $110.11 \pm 6.49$ & $107.89 \pm 8.57$ & $109.56 \pm 4.82$ \\
$\mathrm{ND}_{2} \mathrm{R}$ & $111.00 \pm 5.31$ & $106.56 \pm 6.00$ & $82.56 \pm 7.72$ \\
$\mathrm{ND}_{2} \mathrm{Co}$ & $111.00 \pm 3.80$ & $109.44 \pm 5.20$ & $84.11 \pm 3.55$ \\
$\mathrm{D}_{2} \mathrm{C}$ & $112.67 \pm 4.12$ & $182.22 \pm 15.43$ & $199.00 \pm 5.85$ \\
$\mathrm{D}_{2} \mathrm{R}$ & $110.56 \pm 5.27$ & $184.33 \pm 6.98$ & $148.78 \pm 5.87$ \\
$\mathrm{D}_{2} \mathrm{Co}$ & $111.78 \pm 2.33$ & $183.56 \pm 5.53$ & $164.63 \pm 4.44$ \\
$\mathrm{D}_{2} \mathrm{D}$ & $111.33 \pm 4.52$ & $176.44 \pm 13.42$ & $143.33 \pm 3.00$ \\
\hline
\end{tabular}

FBG- Fasting blood glucose before introduction of HFD. B FBG- Fasting blood glucose after 12 weeks of HFD consumption. 2 FBG- Fasting blood glucose after 2 weeks of extracts administration 4FBG- Fasting blood glucose after 4 weeks of extracts administration Source: Adeniyi and Sanusi [38]. 
At the end of the fourth week of the extracts' administration blood glucose in non-diabetic rats given raw and cooked ginger extracts reduced from 110.90 and $109.40 \mathrm{mg} / \mathrm{dl}$ to 81.60 and $83.60 \mathrm{mg} / \mathrm{dl}$ respectively (Table 13). The blood glucose of the animals at the end of the second week of the extracts' administration was not significantly different from these. This shows that the medium and long term consumption of the spice in both raw and cooked forms is safe and may not lead to clinically threatening hypoglycemia since the values are still within the normal range in fasted state. In the diabetic groups raw and cooked ginger extracts were as effective as the anti-diabetic drug (glybenclamide) in lowering blood glucose to normal level (Table 13). This blood glucose lowering effect of the ginger extracts is evidently the result of the enhanced glucose uptake as reported above (Table 13).

The blood glucose lowering effect of raw and cooked ginger extracts in the non-diabetic rats was similar to that observed in Table 13 (Table 14). Raw ginger extract on the other hand was more effective in lowering the blood glucose to the normal level than the cooked form in the diabetic groups. The cooked form also had a blood glucose lowering effect. It is therefore clearly evidenced from Tables 13 and 14 that the enhancement of glucose uptake by the ginger extracts and drugs in the absence of insulin which was observed in this study favorably reduced the blood glucose which is the expected outcome showing that raw and ginger extracts may be effective in the dietary management of diabetes mellitus.

\section{Conclusion and Recommendation}

Raw and cooked ginger extracts increased glucose uptake by the muscle and adipose tissues of normal and diabetic rats even in the absence of insulin, hence, ginger may be insulin-like in activity and could be of significant importance in the diet therapy for the prevention and management of diabetes mellitus. Human trial is hereby recommended.

\section{References}

[1] Mozaffari-Khosravi H., Talaei B., Jalali B-A., Najarzadeh A. and Mozayan M.R. (2014). The effect of ginger powder supplementation on insulin resistance and glycemic indices in patients with Type 2 diabetes: A randomized double-blind placebo-controlled trial. Complementary Therapies in Medicine; 22(1): 9-16.

[2] Mahluji S., Attari V.E., Mabassori M., Payahoo L., Ostadrahimi A. and Golzari S.E.J. (2013). Effect of ginger (Zingiber officinale) on plasma glucose level, HbA1c and insulin sensitivity in type 2 diabetic patients. International Journal of Food Sciences and Nutrition; 64(6): 682-686.

[3] Son M.J., Miura Y. and Kazum Y. (2014). Mechanism of anti diabetic effect of gingerol in cultured cells and obese diabetic model mice. Cytotechnology.

[4] Sukalingam K., Ganesan K. and Gani S.B. (2013). Hypoglycemic effect of 6-gingerol, an active principle of ginger in streptozotocin-induced diabetic rats. Journal of Pharmacology and Toxicological Studies; 1(2): 23-30.

[5] Abdulrazaq N.B., Cho M.M., Win N.N., Zaman R. and Rahman M.T. (2012). Beneficial effects of ginger (Zingiber officinale) on carbohydrate metabolism in streptozotocin-induced diabetic rats. British Journal of Nutrition; 108(7): 1194-1201.
[6] Jafri S.A., Abass S. and Qasim M. (2011). Hypoglycemic effect of Ginger (Zingiber officinale) in alloxan-induced diabetic rats (Rattus norvagicus). Pakistan Veterinary Journal; 31(2): 160-162.

[7] Anfernan M.L.K. (2014). Evaluation of nutritional and anti diabetic activity of different forms of ginger in rats. Middle East Journal of Scientific Research; 21(1): 56-62.

[8] Akhani S.P., Vishwakarma S.L and Goyal R.K. (2005). Antidiabetic activity of Zingiber officinale Roscoe in streptozotocin-induced non-insulin dependent diabetic rats. Indian Journal of Pharmaceutical Science; 65(5): 553-557.

[9] Kalejaiye O.F., Iwalewa E.O., Omobuwajo O.R. and Oyedapo O.O. (2002). Hypoglycemic effects of Nigerian Zingiber officinale rhizome on experimental diabetic rats. Nigerian Journal of Natural Products and Medicine; 6: 33-35.

[10] Kadnur S.V. and Goyal R.K. (2005). Beneficial effect of Zingiber officinale Roscoe on fructose-induced hyperlipidemia and hyperinsulinemia in rats. Indian Journal of Experimental Biology; 43: 1161-1164.

[11] Islam S. and Choi H. (2008). Comparative effect of dietary ginger (Zingiber officinale) and garlic (Allium sativum) investigated in a type 2 diabetes model of rats. Journal of Medicinal Food; 11(1): 152-159.

[12] Nammi S., Sreemantha S. and Roufogalis B.D. (2009). Protective effects of ethanolic extract of Zingiber officinale rhizome on the development of metabolic syndrome in high-fat diet-fed rats. Basic and Clinical Pharmacology and Toxicology; 104(5): 366-373.

[13] Al-Qattan K., Thomson M. and Ali M. (2008). Garlic (Allium sativum) and ginger (Zingiber officinale) attenuate structural nephropathy progression in streptozotocin-induced diabetic rats. European e-Journal of Clinical Nutrition and Metabolism; 3(2): e62-e71.

[14] Ugwuja E.I., Nwibo A.N., Ugwu N.C. and Aloke C. (2010). Effects of aqueous extract of spices mixture containing curry, garlic and ginger on plasma glucose and lipids in alloxan-induced diabetic rats. Pakistan Journal of Nutrition; 9(12): 1131-1135.

[15] AL-Moramadhi S.A.H. (2010). The effect of Zingiber officinale roots infusion on some physiological parameters in broiler chickens. Kufa Journal of Veterinary MedicalSciences; 1(2) www.uokufa.edu.iq(03/03/2013).

[16] Somani R.S. and Singhai A.K. (2008). Hypoglecemic and hypolipidemic effect of Zingiber officinale in normal and diabetic rats. In Phytopharmacology and Therapeutic Values; eds. Govil J.N. and Singh V.K.; Vol IV: 171-173. Cabdirect, U.K.

[17] Singh A.B., Singh N., Maurya R. and Srivastava A.K. (2009). Anti-hyperglycemic, lipid-lowering and antioxidant properties of [6]-gingerol in $\mathrm{db} / \mathrm{db}$ mice.. International Journal of Medicine and Medical Sciences; 1(12): 536-544.

[18] Al-Amin Z.M., Thomson M., Al-Qattan K.K., Peltonen-Shalaby R. and Ali M. (2006). Antidiabetic and hypolipidemic properties of ginger (Zingiber officinale) in streptozotocin-induced diabetic rats. British Journal of Nutrition; 96(4): 660-666.

[19] Ojewole J.A.O (2006). Analgesic, Antiinflammatory and Hypoglycemic effects of ethanol extract of Zingiber officinale (Roscoe) rhizomes in mice and rats. Phytotherapy Research: 20: 764-772.

[20] Elshater A.A., Salman M.M.A. and Moussa M.M.A. (2009). Effect of Ginger extract consumption on levels of blood glucose, lipid profile and kidney functions in alloxan-induced diabetic rats. Egyptian Academic Journal of Biological Sciences; 2(1): 153-162.

[21] Akhani S.P., Vishwakarma S.L. and Goyal R.K. (2004). Anti diabetic activity of Zingiber officinale in streptozotocin-induced Type 1 diabetic rats. Journal of Pharmacy and Pharmacology; 56: 101-105.

[22] Sharma M. and Shukla S. (1977). Hypoglycemic effect of ginger.Journal of Research onIndian Yoga and Homeopathy. ; 12: 127-130.

[23] Satiel A.R and Kahn C.R. (2001). Insulin signaling and the regulation of glucose and lipid metabolism. Nature; 404: 799-806.

[24] Imamura T., Huang J., Usui I., Satoh H., Bever J. and Olefsky J.M. (2003). Insulin-induced GLUT4 translocation involves protein kinase $\mathrm{C}-\lambda$-mediated functional coupling between Rab4 and the motor protein kinesin. Molecular and Cellular Biology; 23(14): 4892-4900.

[25] Huang S. and Czech M.P. (2007). The GLUT4 glucose transporter. Cell metabolism; 5(4): 237-252. 
[26] Rani M.P., Krishna M.S., Padmakumari P., Raghu K.G. and Sundaresan A. (2012). Zingiber officinale extract exhibits antidiabetic potential via modulating glucose uptake, protein glycation and inhibiting adipocyte differentiation: an in vitro study. Journal of the Science of Food and Agriculture; 92(9): 1948-1955.

[27] Son M.J., Miura Y. and Kazum Y. (2014). Mechanism of anti diabetic effect of gingerol in cultured cells and obese diabetic model mice. Cytotechnology.

[28] Noipha K. and Ratanachaiyavong S. (2008). Effect of ginger (Zingiber officinale Roscoe) on glucose transport in cultured skeletal muscle cells. Journal of Thai Traditional and Alternative Medicine; 6(2): 82-87.

[29] Martinello F., Soares S.M. and Franco J.J. (2006). Hypolipidemic and antioxidant activates from Tamarindus indica pulp fruit extract in hypercholesterolemic hamsters. Food and Chemical Toxicology; 44(6): 810-818.

[30] Kergoat M. and Portha B. (1985). In vivo hepatic and peripheral insulin sensitivity in rats with non-insulin-dependent diabetes induced by streptozocin. Assessment with the insulin-glucose clamp technique. Diabetes; 34(11): 1120-6.

[31] Gupta R.K., Kesari A.N., Watal G., Murthy P.S., Chandra R. Mathal K and Tandon V. (2005). Hypoglycemic and antidiabetic effect of aqueous extract of leaves of Annona squamosa (L.) in experimental animal. Current Science; 88(8): 1244-1254.

[32] Broadhurst C.L., Polansky M.M.and Anderson R.A. (2000). Insulin-like biological activity of culinary and medicinal plant aqueous extracts in vitro. Journal of Agricultural and Food Chemistry; 48(3): 849-852.

[33] Li Y., Tran V.H., Koolaji N., Duke C. and Roufogalis B.D. (2013). [S]-[6]-gingerol enhances glucose uptake in L6 myotubes by activation of AMPK in response to $\left[\mathrm{Ca}^{2+}\right]$. Journal of Pharmacy and Pharmaceutical Sciences; 16(2): 304-312.

[34] Li Y., Tran V.H., Kota B.P., Nammi S., Duke C.C. and Roufogalis B.D. (2014). Preventive effect of Zingiber offinale on insulin resistance in a high-fat high-carbohydrate diet-fed rat model and its mechanism of action. Basic Clinical Pharmacology and Toxicology; 115(2): 209-215.

[35] Sekiya K., Ontani P. and Kusano S. (2004). Enhancement of insulin sensitivity in adipocytes by ginger. Biofactors; 22(1-4): 152-156.

[36] Gannon N.P., Conn C.A., and Vaughan R.A. (2014). Dietary stimulators of GLUT4 expression and translocation in skeletal muscle: A mini-review. Molecular Nutrition and Food Research; 59(1): 48-64.

[37] Adeniyi P.O. and Sanusi R.A. (2014). Effect of ginger (Zingiber officinale) extracts on blood glucose in normal and STZ-induced diabetic rats. International Journal of Clinical Nutrition; 2(2): 32 35.

[38] Adeniyi P.O. and Sanusi R.A. (2014). Efficacy of ginger (Zingiber officinale) extracts in lowering blood glucose in normal and High Fat diet-induced diabetic rats. American Journal of Food and Nutrition; 2(4): 55-58. 